\title{
ATP-Binding Cassette Sub-Family A Member 2
}

National Cancer Institute

\section{Source}

National Cancer Institute. ATP-Binding Cassette Sub-Family A Member 2. NCI Thesaurus.

Code C89025.

AT P-binding cassette sub-family A member 2 (2435 aa, $270 \mathrm{kDa}$ ) is encoded by the human ABCA2 gene. This protein may be involved in the modulation of lipid metabolism and neural development. 